\title{
Virulence Structure and Diversity of Puccinia coronata f. sp. avenae P. Syd. \& Syd. in Poland During 2013 to 2015
}

\author{
Edyta Paczos-Grzęda ${ }^{\dagger}$ and Sylwia Sowa \\ Institute of Plant Genetics, Breeding and Biotechnology, University of Life Sciences in Lublin, 20-950 Lublin, Poland
}

\begin{abstract}
The crown rust fungus Puccinia coronata f. sp. avenae P. Syd. \& Syd. $(P c a)$ attacks cultivated oat and its wild relatives, causing significant losses to the crop worldwide. Although understanding the origin and dynamics of the pathogen's diversity is critical to developing methods for its control, there are little relevant data on $P c a$ virulence diversity in Europe, the global center of oat production. The goal of this study was to analyze the diversity of $P c a$ populations in Poland in 2013 to 2015 based on their ability to overcome currently available host resistance $P c$ genes. $P c a$ isolate virulence was evaluated on a panel of lines containing 26 major resistance genes of oat. The isolates were able to overcome from 1 to 16 resistance genes each, with most isolates being virulent on five to seven

lines. In all years, a very high level of crown rust pathotype diversity was observed, with Simpson and Evenness indices of 0.99. In total, 156 different pathotypes were detected, with no prevalent pathotype in any of the 3 years analyzed. The results showed that the virulence level of $P$. coronata isolates was relatively low for each year studied ( $21 \%$ on average), most likely owing to the low take up of $P c$ genes in Polish oat cultivars, meaning that many sources of resistance are still effective against $P c a$ races occurring in Poland. The long-range dispersal of Puccinia spores supported by the availability of wild, weedy, and cultivated Avena species makes it likely that the virulence profile seen in Poland is representative of much of central Europe and beyond.
\end{abstract}

Crown rust caused by the obligate biotrophic fungus, $P c a$ P. Syd. \& Syd. ( $P c a)$, is considered to be the most damaging disease of oat (Avena sativa L.) worldwide (Chong 2003). Under favorable conditions in areas with warm temperatures $\left(20\right.$ to $\left.25^{\circ} \mathrm{C}\right)$ and high humidity during the growing season, crown rust can lead to a total crop failure (Carson 2009c). Losses result from damage to all aerial green parts of the plant (leaves, leaf sheaths, panicles, and floral structures), especially the flag leaves, on which orange-yellow uredinia (pustules) containing newly formed urediniospores develop. Photosynthesis is reduced, leading to a significant decrease in the transport of carbohydrates to the developing grain and lowering its quality. Heavy rust infection weakens straw development, which exacerbates lodging. Diseased plants are also less tolerant to drought because of the reduced root system (Fetch et al. 2011; Nazareno et al. 2018; Simons 1985).

Control of oat crown rust is mainly based on the use of resistant varieties; however, new resistances rarely protect cultivars for $>3$ to 5 years (Park 2013) as a consequence of the highly dynamic nature of the pathogen population. The rapid emergence of new rust pathotypes differing in virulence and aggressiveness is linked to the lifecycle of the pathogen, which involves sexual and asexual reproduction (Carson 2011). For much of this cycle, Pca is dikaryotic, with two separate haploid nuclei that may differ in their contribution to virulence. This asexual phase for $P c a$ occurs on cultivated oat and its wild relatives. Clonal reproduction occurs in repeated infection and sporulation cycles. Mutation and somatic recombination during this asexual phase may play significant roles in the

\section{${ }^{\dagger}$ Corresponding author: E. Paczos-Grzęda; edyta.paczos@up.lublin.pl}

Funding: This research was supported by Ministry of Agriculture and Rural Development of the Republic of Poland grant 2014-2020: "Crown rust resistance genes pyramiding in oat genome and identification of DNA markers for these genes."

The author(s) declare no conflict of interest.

Accepted for publication 14 January 2019.

(c) 2019 The American Phytopathological Society emergence of new pathotypes (Bartos et al. 1969; Park 2008; Park and Wellings 2012), but the main opportunity for new virulence combinations to arise is during the sexual phase, which takes place on both oat and the alternative host, Rhamnus species. Rhamnus leaves are infected by haploid basidiospores produced by meiosis from teliospores, which are thick-walled survival structures on the genus Avena. Subsequently, gamete fusion takes place to reestablish the dikaryotic stage (Simons 1985). Thus, the sexual phase contributes to the generation of an additional source of inoculum as well as the increase of genetic variability in the population of the pathogen (Berlin et al. 2018; Zhao et al. 2016).

The contribution of each phase to $P c a$ diversity is difficult to determine. Despite the cosmopolitan distribution of the genus Rhamnus, susceptible species may be rare in some regions, restricting sexual reproduction of $P$. coronata (Simons 1985). Even where a susceptible alternate host is present (such as, for example, in the case of Rhamnus cathartica, which is common in Poland) (Mirek et al. 2002), winters may be too cold for urediniospores to survive. No data are available to assess the role of this species as an alternate host for $P c a$ in central Europe, and the main source of inoculum in this region may be migrating $P c a$ spores, which has been suggested elsewhere (Fetch et al. 2011). P. coronata urediniospores can travel very long distances transmitted by wind (Simons 1985), whereas migrating birds may contribute to the spread of spores even across continents (da Silva et al. 2016).

In Europe, detailed studies of $P$. coronata virulence were carried out in the years 1992 to 1993 as a part of a global survey (Šebesta et al. 2003). Additional data regarding European Pca population diversity covered the period from 2004 to 2006 in the Czech Republic (Jiráková and Hanzalová 2008). The local population structure may play a significant role in disease spread and severity, and therefore, the aim of this study was to assess the virulence of $P c a$ isolates collected throughout Poland during the years 2013 to 2015. An additional goal was preliminary evaluation of $P c$ race-specific resistance genes and their potential for use in practical breeding in the central European growing conditions.

\section{Materials and Methods}

Samples of $P$. coronata were collected in the years 2013 to 2015 from farm fields of three oat breeding companies in Poland (Strzelce, Polanowice, and Kopaszewo) and the experimental farm of the 
University of Life Sciences in Lublin (Czesławice) (circles on the map in Fig. 1) as well as experimental stations of the Research Centre for Cultivar Testing (squares on the map in Fig. 1). Each sample was gathered from different oat field plots of $P c a$ susceptible reference cultivars Bingo, Zuch, and Krezus. The number of samples collected was determined by the virulence intensity in a given year. Not all areas in Poland were represented by isolates in each year, and the total number of isolates from most areas was $<10$. Thus, it was not feasible to compare frequencies of virulence on specific differentials between areas.

Oat leaves with visible disease symptoms were trimmed to a single uredinium and placed into petri dishes filled with agar $(0.6 \%)$ containing benzimidazole (3.4 mM). Single-uredinia isolates were multiplied in a phytotron on the susceptible oat cultivar Kasztan based on the host-pathogen methodology developed by Hsam et al. (1997). Leaf fragments of Kasztan (3-cm long) were placed onto petri dishes with water agar medium prepared as above and inoculated in a settling tower by applying 500 to 700 spores of $P$. coronata per $1 \mathrm{~cm}^{2}$. The dishes were then incubated in a phytotron for 10 days at $18^{\circ} \mathrm{C}$ with $70 \%$ humidity and illuminance of $\sim 4 \mathrm{kLx}$ for a $16-\mathrm{h}$ photoperiod.

The virulence level of multiplied $P c a$ isolates was determined on 26 reference oat lines carrying different crown rust resistance genes (below). Laboratory tests were carried out on three leaf fragments, each from a different seedling of one Avena genotype using the above-mentioned procedure. Leaves were placed onto 12-well culture plates filled with agar, and Kasztan was used as an infection control in each well. Resistance reactions were determined 10 days after inoculation and scored according to a qualitative scale of susceptible (S; large to moderately large pustules with little or no chlorosis), moderately susceptible (MS; moderately large pustules surrounded by extensive chlorosis), moderately resistant (MR; small pustule surrounded by chlorosis), resistant (chlorotic or necrotic flecking), and highly resistant (no visible reaction) (Carson 2009a; Sowa et al. 2016). If disease symptoms were scored as S, MS, or MR, the isolates were classified as virulent to tested $P c$ genes; otherwise, the $P$. coronata isolates were regarded as being avirulent.

Differential oat lines were developed at either Iowa State University of Science and Technology, Ames, Iowa, U.S.A. (Pc51, Pc52,

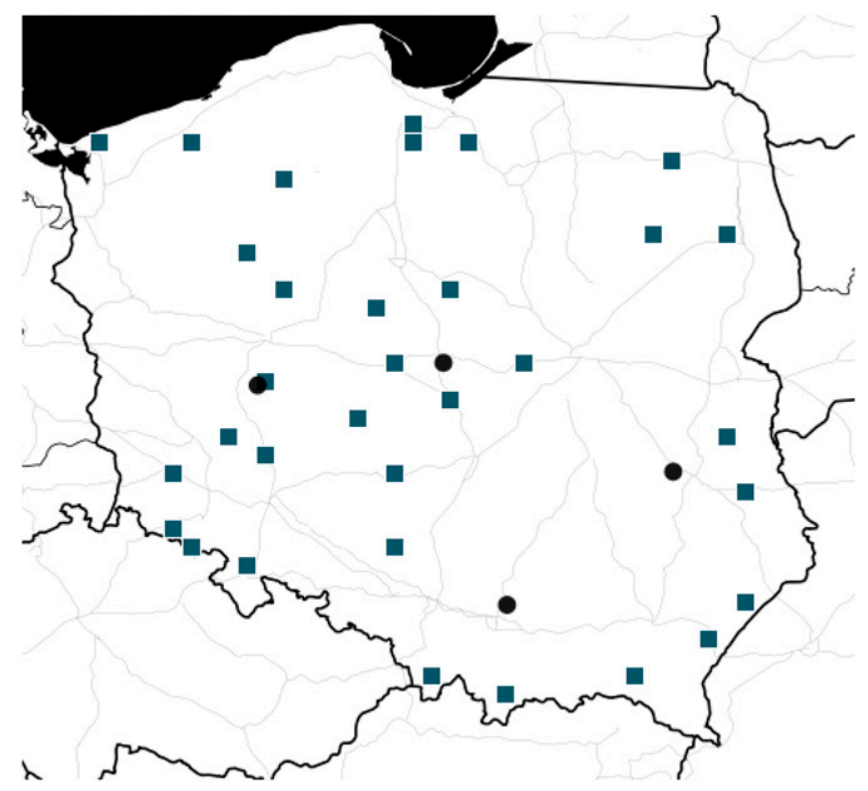

Fig. 1. The geographical distribution in Poland of Puccinia coronata isolates used for the study of crown rust virulence structure and diversity in the years 2013 to 2015. Squares indicate locations of experimental stations of the Research Centre for Cultivar Testing. Circles indicate the locations of experimental farm fields of oat breeding companies.
$P c 70$, and $P c 71)$ or Cereal Research Centre, Agriculture \& AgriFood Canada, Winnipeg, Manitoba, Canada (Pc39, Pc40, Pc45, Pc48, Pc50, Pc54, Pc55, Pc56, Pc57, Pc62, Pc68, Pc91, Pc94, Pc96, Pc97, Pc98, Pc101, Pc103-1, and Pc104) (Carson 2011; Chong et al. 2011; Menzies et al. 2015). Additionally, cultivars TAM-O-301 and TAM-O-312 developed at Texas A\&M University, College Station, Texas, U.S.A. were representatives for Pc58 and Pc59, whereas cultivar Coker227 (developed by the Coker's Pedigreed Seed Company, Hartsville, South Carolina, U.S.A. served as the Pc60 gene reference (Simons et al. 1978) (Table 1).

\section{Data Analysis}

Virulence within the pathogen population was quantified based on the proportion of susceptible lines to an isolate in each year and the pattern of virulence in the differential reference line panel. Results were subjected to the Kruskal-Wallis one-way analysis of variance appropriate for data with distributions far from normal with the mean ranks post hoc comparison.

The virulence structure of the crown rust population in a given year was described by the complexity and frequency of virulence. The number of differential lines to which each isolate was virulent provided a measure of virulence complexity. Virulence frequency $(p)$ was calculated for each differential according to the formula

$$
p=\frac{x}{N}
$$

where $x$ is the number of times that a virulent reaction type was detected and $N$ is the number of all tested isolates in the sample.

Pathogen diversity with respect to particular years was described using the Simpson Diversity Index $(S)$ and the Evenness Index (EH) (Groth and Roelfs 1987; Müller et al. 1996; Simpson 1949). Simpson Diversity Index $(S)$ was calculated as

$$
S=1-\sum_{i=1}^{s} \frac{n_{i}\left(n_{i}-1\right)}{N(N-1)},
$$

where $n_{i}$ is the number of isolates of the $i$ th pathotype, $s$ stands for the number of observed pathotypes in the sample, and $N$ is the total number of isolates in the sample. The Evenness Index $(E H)$ was obtained from the formula based on the Shannon Index $\left(H^{\prime}\right)$ and estimated as

$$
\begin{gathered}
E H=\frac{H^{\prime}}{H_{\max }} \\
H^{\prime}=-\sum_{i=1}^{s} p_{i} \ln p_{i} \\
H_{\text {max }}=\ln R,
\end{gathered}
$$

where $p_{i}$ is the frequency of the $i$ th virulence phenotype in the sample (Payne et al. 2005).

Data were transformed into a zero/one matrix that recorded the virulence (zero) or avirulence (one) of $P$. coronata isolates to tested crown rust resistance genes. To highlight similarities and differences and visualize the relationships between individual $P$. coronata isolates, principal component analysis was performed (Smith 2002) based on Dice similarity indices (Dice 1945).

Analyses were performed using Statistica 13.1 (StatSoft 2017), Microsoft Excel 2010, and PAST 3.19 software (Hammer et al. 2001).

\section{Results}

Weather conditions were unfavorable to $P$. coronata infection in 2013 , leading to the lowest crown rust intensity of the period studied. Isolates in this year were able to overcome between 8 and $54 \%$ of oat differential resistance lines, with an average value of $21 \%$. In 2014 , the level of virulence was between 4 and $62 \%$ with the same average; in 2015, it ranged between 4 and 54\%, and the average value was $22 \%$ (Fig. 2). The Kruskal-Wallis one-way analysis of variance 
did not reveal statistically significant differences between the rates of virulence of $P c a$ populations collected in these years.

Significant levels of virulence against reference genes were seen. Crown rust isolates were able to overcome from 1 to 14 reference genes in 2013 and 2015. Almost one-quarter of the isolates collected in 2013 and 2014 overcame five of these genes, whereas in 2015 , one-fifth of tested isolates was virulent against seven $P c$ genes (Fig. 3). Most significantly, in 2014, $2 \%$ of isolates were virulent toward $16 P c$ reference lines.

The frequency of virulence to each of the 26 individual $P c$ gene differential lines was relatively stable except for the virulence in relation to $P c 48, P c 58$, and $P c 103-1$, which increased markedly over time, and $P c 59$, which was detected at low frequencies only in 2014 and undetected in 2013 and 2015 (Fig. 4). A minor increase of $10 \%$ in the virulence was also recorded for the genes $P c 48$ and $P c 58$. $P c a$ resistance genes $P c 52, P c 71$, and $P c 91$ were the most efficient, although in 2015, the resistances of $P c 52$ and $P c 71$ were overcome by two and one $P c a$ pathotype, respectively. The lowest level of effectiveness was presented by genes Pc103-1, Pc62, and Pc56, with Pc103-1 being the most susceptible of all reference lines in 2015 (85\%) (Fig. 4 and Table 1).

$P c a$ population diversity was very high. Of 162 isolates collected (39 in 2013, 62 in 2014, and 61 in 2015), there were 37 pathotypes in 2013, 60 in 2014, and 59 in 2015 (Table 2). A total of 154 pathotypes with unique virulence profiles were recorded (i.e., $<4 \%$ of isolates were potentially identical). The genetic diversity of virulence factors described by the Simpson Diversity Index $(S)$ as indicating the number of different pathotypes (richness) and the degree of predominance of some pathotypes (evenness) in the population equaled 0.99 for each analyzed year. This means that the probability of obtaining two distinct pathotypes when randomly drawing two isolates from the sample is $99 \%$. For $\mathrm{Pca}$ isolates collected each year, the Evenness Index $(E H)$ indicated that the degree of predominance of some races was also calculated as 0.99 . If the pathotypes occur in similar frequencies, the value of $E H$ is equal to one, whereas if they occur in highly varying frequencies, $E H$ is equal to zero (Table 2).

Principal coordinate analysis based on Dice similarity indices was performed for the $162 \mathrm{Pca}$ isolates. The first 15 components (with eigenvalues greater than one) explained $69.7 \%$ of the variation. On the scatterplot of the first two coordinates (Fig. 5), no major group was clearly identified, which reflects the diversity of the population as well as the high variability of virulence.

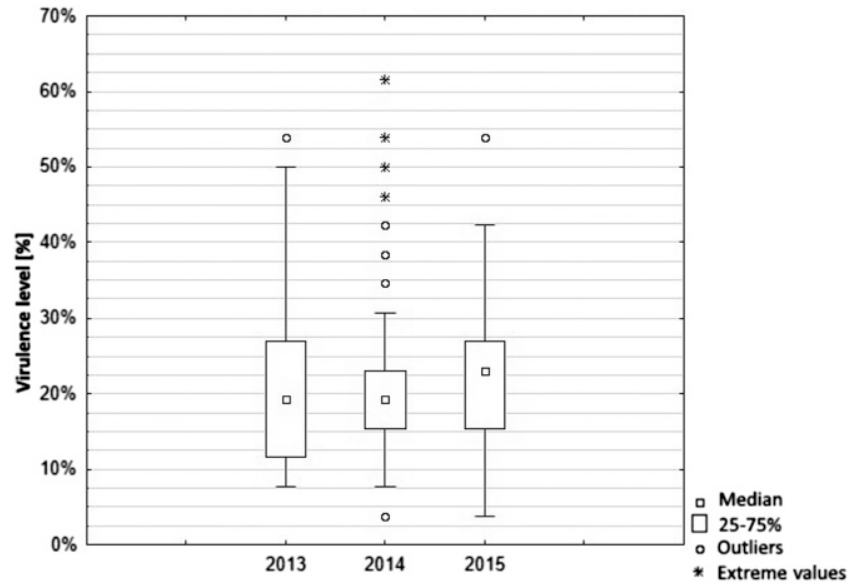

Fig. 2. Box plot of virulence frequency of the Puccinia coronata collected in Poland toward Avena sativa lines carrying different $P c$ resistance genes.

Table 1. The list of 26 oat differentials ranked according to the level of resistance efficiency to Puccinia coronata isolates collected in the years 2013 to 2015 in Poland

\begin{tabular}{|c|c|c|c|c|c|c|c|}
\hline \multirow[b]{2}{*}{ Oat differential line } & \multirow[b]{2}{*}{ Origin $^{\mathbf{a}}$} & \multirow[b]{2}{*}{ Original source } & \multirow[b]{2}{*}{ Tester line } & \multicolumn{4}{|c|}{ Level of efficiency, \% } \\
\hline & & & & 2013 & 2014 & 2015 & Mean value \\
\hline$P c 91$ & AAFC-CRC & Avena magna & Amaglon PI497742 & 100 & 100 & 100 & 100 \\
\hline Pc71 & ISU & Avena sterilis IA B437 & IA Y345 or IA D526 & 100 & 100 & 98 & 99 \\
\hline Pc52 & ISU & Avena sterilis Wahl No. 2 & Iowa isoline $\mathrm{X} 421$ & 100 & 100 & 97 & 99 \\
\hline Pc60 & Coker's Pedigreed Seed Co. & Avena sterilis PI 287211 & Coker 227 & 97 & 100 & 93 & 97 \\
\hline Pc59 & TAMU & Avena sterilis PI 296244 & TAM-O-312 & 100 & 90 & 100 & 97 \\
\hline Pc50 & AAFC-CRC & Avena sterilis $\mathrm{CW}-486$ & Pendek $\times$ Pc50 & 92 & 97 & 97 & 95 \\
\hline Pc51 & ISU & Avena sterilis Wahl No. 8 & Iowa isolines $\mathrm{X} 270$ and $\mathrm{X} 434$ & 97 & 92 & 98 & 96 \\
\hline$P c 70$ & ISU & Avena sterilis PI318282 & H547 & 97 & 98 & 85 & 93 \\
\hline Pc68 & AAFC-CRC & Avena sterilis CAV 4904 & Makuru//Sun II/Pc68 & 85 & 95 & 95 & 92 \\
\hline$P c 101^{\mathrm{b}}$ & AAFC-CRC & Avena sterilis PI334961 & Harmon $\times$ PI 334961 & 90 & 89 & 97 & 92 \\
\hline$P c 104^{\mathrm{b}}$ & AAFC-CRC & Avena sterilis GS1 & Morgan $\times$ GS1 & 85 & 87 & 100 & 91 \\
\hline Pc57 & AAFC-CRC & Avena sterilis CI 8295 & H-555 or IA D640 & 90 & 81 & 93 & 88 \\
\hline Pc94 & AAFC-CRC & Avena strigosa (RL1697) & - & 85 & 90 & 79 & 85 \\
\hline$P c 98^{\mathrm{b}}$ & AAFC-CRC & Avena sterilis CAV 1979 & Harmon $\times$ CAV 1979 & 79 & 71 & 95 & 82 \\
\hline$P c 96$ & AAFC-CRC & Avena sativa MG 85039 & - & 82 & 81 & 80 & 81 \\
\hline Pc39 & AAFC-CRC & Avena sterilis $\mathrm{F}-366$ & Pendek $\times$ Pc39 & 69 & 84 & 84 & 79 \\
\hline Pc48 & AAFC-CRC & Avena sterilis F-158 & Pendek $\times$ Pc48 & 87 & 81 & 69 & 79 \\
\hline Pc58 & TAMU & Avena sterilis PI 295919 & TAM-O-301 & 90 & 84 & 62 & 79 \\
\hline Pc55 & AAFC-CRC & Avena sterilis CAV 4963 & Pendek $\times$ Pc55 & 62 & 60 & 74 & 65 \\
\hline Pc45 & AAFC-CRC & Avena sterilis F-169 & Pendek $\times$ Pc45 & 56 & 69 & 56 & 60 \\
\hline Pc54 & AAFC-CRC & Avena sterilis CAV 1832 & Pendek $\times$.CAV1832 & 62 & 52 & 61 & 58 \\
\hline$P c 40$ & AAFC-CRC & Avena sterilis F-83 & Pendek $\times$ Pc40 & 59 & 55 & 49 & 54 \\
\hline$P c 97^{\mathrm{b}}$ & AAFC-CRC & Avena sterilis CAV 1180 & Harmon $\times$ CAV 1180 & 59 & 55 & 49 & 54 \\
\hline$P c 56$ & AAFC-CRC & Avena sterilis CAV 1964 & Pendek $\times$ Pc56 & 41 & 65 & 39 & 48 \\
\hline Pc62 & AAFC-CRC & Avena sterilis CAV 4274 & Fraser $\times$ Pc62 & 44 & 40 & 54 & 46 \\
\hline$P c 103-1^{\mathrm{b}}$ & AAFC-CRC & Avena sterilis PI333463 & Harmon $\times$ PI 333463 & 51 & 35 & 15 & 34 \\
\hline
\end{tabular}

a AAFC-CRC, Cereal Research Centre Agriculture \& Agri-Food Canada, Winnipeg, Manitoba, Canada; Coker's Pedigreed Seed Co., Coker's Pedigreed Seed Company, Hartsville, South Carolina; ISU, Iowa State University of Science and Technology, Ames, Iowa; TAMU, Texas A\&M University, College Station, Texas.

${ }^{\mathrm{b}}$ Pedigrees of lines $P c 97, P c 98, P c 101, P c 103-1$, and Pc104 were provided by $\mathrm{J}$. Chong (unpublished data). 


\section{Discussion}

$P c a$ is a ubiquitous and highly adaptable fungus. It occurs worldwide, but Europe is particularly vulnerable to crown rust outbreaks, having suitable hosts and weather conditions (Simons 1985). This paper reveals the diversity of virulence of $\mathrm{Pca}$ in Poland based on 162 isolates collected from different oat field plots during the years 2013 to 2015 . Each single-uredinia isolate was tested on 26 differential oat lines using a reproducible host-pathogen test. This is the first study that concerns the analysis of $P c a$ virulence in a European country in relation to $P c 91, P c 97, P c 98, P c 101, P c 103-1$, and $P c 104$ resistance genes.

In this study, virulence within the pathogen population in each year was at approximately the same relatively low level of $21 \%$, most likely owing to the lack of resistant Polish oat cultivars driving selection pressure on the pathogen (Paczos-Grzęda et al. 2014). However, in all years, a very high level of $P$. coronata diversity was observed. The diversity was assessed for richness, indicating the total number of different pathotypes in the population, as well as for evenness, representing the extent of predominance of some races in the total

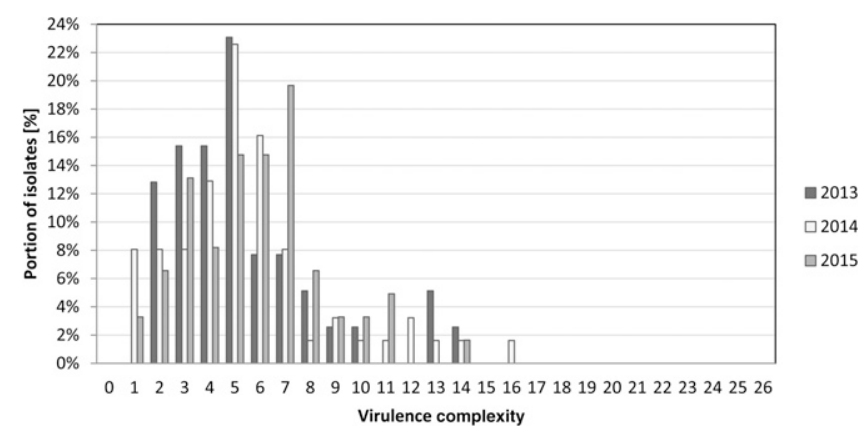

Fig. 3. Virulence complexity of 162 Puccinia coronata isolates collected in Poland during the years 2013 to 2015 and tested on 26 differential lines in the seedling stage.

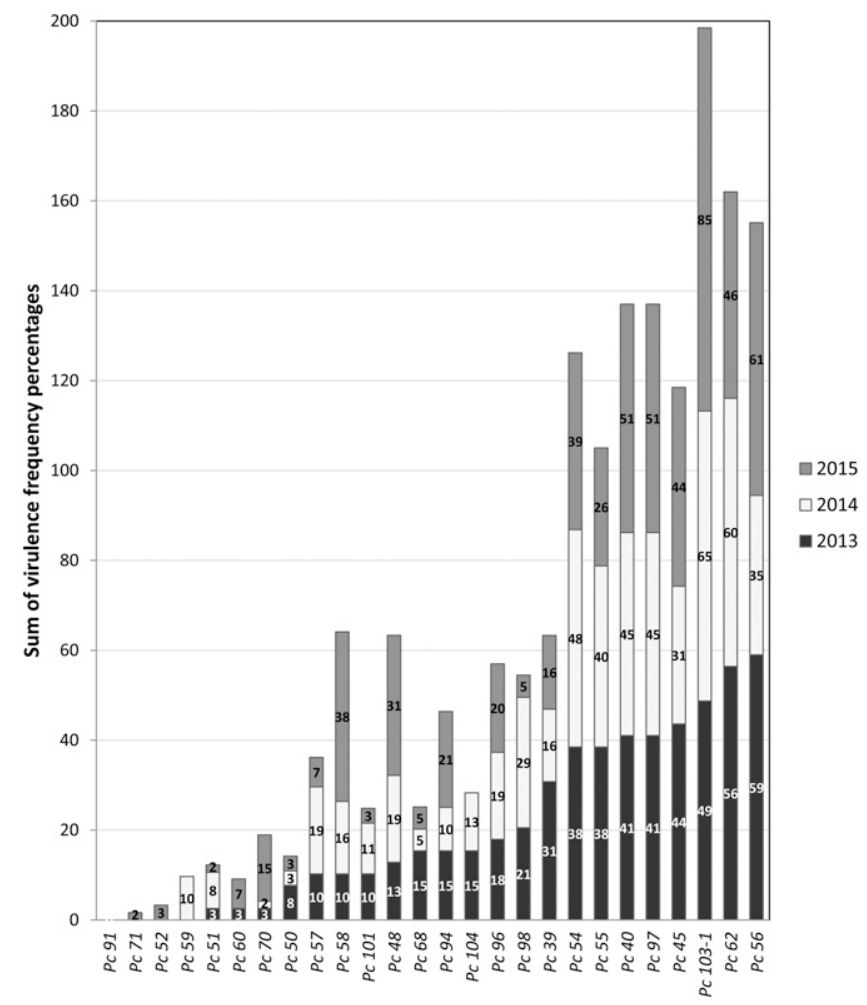

Fig. 4. Total virulence frequencies (percentages) of 162 Puccinia coronata isolates collected in Poland in the years $2013(n=39), 2014(n=62)$, and $2015(n=61)$ on each differential oat genotype. population. These properties were described by means of the Simpson Diversity Index $(S)$ and the Evenness Index $(H)$, the normalized version of the Shannon Index. Because of the varying sample sizes, the Simpson Diversity Index and the Evenness Index proved to be suitable measures, insensitive to divergent sizes of the populations being compared (Herrmann et al. 1999; Klocke et al. 2013). For each year analyzed, both indices were 0.99 , almost the maximum level of diversity (1.00). The results show that $P c a$ pathotypes in Poland are highly diverse and evenly distributed. Such high diversity in virulence patterns is not unexpected given that many studies conducted worldwide confirm the variable nature of $P$. coronata. Long-term screening of $\mathrm{Pca}$ virulence was carried out intensively in Canada (Chong and Zegeye 2004; Chong et al. 2008, 2011; Menzies et al. 2015) and the United States (Carson 2008, 2011), where oat varieties with resistance based on the major $P c$ genes (e.g., $P c 38, P c 39, P c 48$, $P c 68, P c 91, P c 94$, and $P c 96)$ have been introduced into breeding from the 1920s (Gnanesh et al. 2014). This research indicated that the crown rust population is highly diverse regardless of the isolates' region of origin; however, some of the differences in virulence frequency reflect the use of corresponding resistance genes in the particular regions (Carson 2008). The ubiquitous presence of an alternative $P c a$ host on which sexual propagation takes place is expected to contribute to this diversity. Crown rust resistance strategies in oat breeding rely on the classical gene-for-gene model and involve the introduction of major resistance $(P c)$ genes into cultivars (Chong et al. 2000; Flor 1971). These genes often encode intracellular immune receptor proteins with nucleotide-binding sites (NBS) and leucine-rich repeats (LRR), which directly or indirectly recognize pathogen-derived virulence effectors (Avr) delivered into the host cell cytoplasm during infection (Jones and Dangl 2006; Periyannan et al. 2017). The evolution of new virulence factors occurs as a result of changes in effector genes that allow the pathogen to avoid recognition (Krattinger and Keller 2016). Genome sequencing has revealed that effector genes are not randomly distributed but preferentially located in compartments enriched in transposable elements and repetitive sequences, leading to the "two-speed genome" model for rapid effector gene evolution and consequent adaptation to new host genotypes (Dong et al. 2015). However, analysis of the Pca genomes showed no significant association between orthologous effector

Table 2. Puccinia coronata pathotype diversity in Poland for the years 2013 to 2015

\begin{tabular}{|c|c|c|c|c|c|}
\hline \multirow[b]{2}{*}{ Year } & \multirow{2}{*}{$\begin{array}{l}\text { Number } \\
\text { of isolates }\end{array}$} & \multirow{2}{*}{$\begin{array}{l}\text { Number of } \\
\text { pathotypes }\end{array}$} & \multirow{2}{*}{$\begin{array}{c}\text { Number of specific } \\
\text { pathotypes }\end{array}$} & \multicolumn{2}{|c|}{ Diversity } \\
\hline & & & & $S^{\mathrm{a}}$ & $\overline{E H^{\mathrm{b}}}$ \\
\hline 2013 & 39 & 37 & 35 & 0.99 & 0.99 \\
\hline 2014 & 62 & 60 & 58 & 0.99 & 0.99 \\
\hline 2015 & 61 & 59 & 57 & 0.99 & 0.99 \\
\hline
\end{tabular}

a Simpson Diversity Index.

${ }^{\mathrm{b}}$ Evenness Index - normalized version of the Shannon Index.

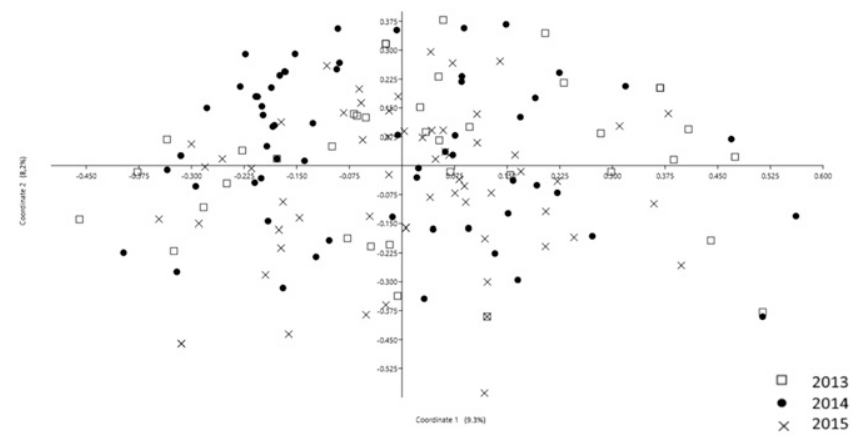

Fig. 5. Principal component analysis of 162 Polish Puccinia coronata isolates collected during the years 2013 to 2015 based on their reaction to 26 oat differentials revealed high diversity of races. 
genes and repeat elements in support of this model (Miller et al. 2018).

An alternative explanation for the high diversity of virulence may be a combination of conventional mutation and somatic hybridization with rapid long-range dispersal. Many studies suggest that periodic introductions of exotic, genetically different isolates contribute to the pathogen populations (Brake et al. 2001). Disease occurrence is closely related to the prevailing wind directions in the fungus sporulation phase, and the phenomenon of periodic $P$. coronata spore movement has been observed in various parts of the world. One of the best known examples is the "Puccinia pathway," along which urediniospores from northern Mexico and southern Texas move to the north-central region of the United States and the provinces of Manitoba and Saskatchewan in Canada during early summer (Harder and Haber 1992). Hovmøller et al. (2002) provided evidence for similar spore migration routes while studying Puccinia striiformis $\mathrm{f}$. sp. tritici in northwest Europe. Limpert et al. (1999, 2000), studying the barley and wheat mildew pathogens (Blumeria [Erysiphe] graminis $\mathrm{f}$. sp. hordei and tritici, respectively), noticed a significant increase of virulence complexity from the west to east across Europe. This is consistent with results of this study showing the occurrence of $P$. coronata races with high complexity reaching 16 virulence types per genotype as well as the presence of virulence against resistance $(P c)$ genes, although they were not used in Polish oat cultivars. Selection on Avena cultivars with different $P c$ genes at earlier stages of spore migration may then have driven virulence diversity downwind.

The dikaryotic nature of the $P c a$ asexual phase provides opportunities for generating diversity by somatic hybridization (Bartos et al. 1969). Actual mechanisms are still unclear (Park and Wellings 2012), but they may involve fusion of dikaryotic vegetative hyphae, nuclear exchange, and possibly, exchange of whole chromosomes between nuclei. A parasexual cycle may occur by fusion of two haploid nuclei followed by mitotic crossing over and vegetative haploidization (Park and Wellings 2012; Tinline and MacNeill 1969).

This study also provides a preliminary evaluation of the potential of $P c$ race-specific genes for use in practical breeding in central European conditions. The genes $P c 52, P c 71$, and $P c 91$ were seen to be the most efficient. During the 3 years studied, no isolates overcoming the resistance of $P c 91$ were found. In 2015, only one pathotype broke the resistance of $P c 71$, whereas two were virulent toward $P c 52$. The donor of Pc91 is tetraploid Avena magna (McMullen et al. 2005; Rooney et al. 1994), whereas $P c 52$ and $P c 71$ were identified in the hexaploid wild oat Avena sterilis (Frey et al. 1985). Pc91 is already widely used in oat breeding, deployed both singly and in combination with other genes (Gnanesh et al. 2014; Park 2013). Pc91 seemed to be an extremely strong and effective source of resistance; however, virulence to this gene has already been recorded in Canada (Chong et al. 2008; McCartney et al. 2011; Menzies et al. 2015), the United States (Carson 2009b), and Australia (Park 2013). Currently, there is no information on $P c 91$ efficiency in other European countries. There are also no data regarding the effectiveness of $P c 97, P c 98$, Pc101, Pc103-1, and Pc104 genes. The only reports of studies on these genes are from Menzies et al. (2015), who characterized the virulence of Canadian P. coronata isolates collected from 2010 to 2014. None of the tested genes provided total immunity to the isolates used in the study. $P c 94, P c 98$, and $P c 101$ were highly effective, providing resistance to almost every eastern and western Canadian isolate and corresponding with our results. The researchers have also detected an increase of virulence in Canada in relation to Pc103-1, reaching nearly $20 \%$, whereas in our research, $P c 103-1$ was the least effective resistance gene. Interestingly, a significant increase of virulence against $P c 91$ in western Canada was observed (from $0 \%$ in 2010 and 2011 to $45 \%$ in 2014), probably caused by an extension of the growing area of commercial cultivars possessing this resistance gene. $P c 52$ efficiency decreased significantly in 2014 , whereas $P c 71$ was not included in the study.

The monitoring of changes in the Pca population in Europe has been rather limited. Several studies were carried out before 2001 (Šebesta et al. 1997, 2003). The work of Jiráková and Hanzalová (2008) has data concerning Pca pathotypes collected in the Czech
Republic from 2004 to 2006. Researchers listed Pc39, Pc50, Pc59, $P c 60$, and $P c 68$ as highly effective, which is in agreement with our results. However, Jiráková and Hanzalová (2008) included Pc62 in the list of effective genes, which provided resistance to all tested $P$. coronata samples. Its effectiveness in relation to Polish $P$. coronata pathotypes was very low at the level of $46 \%$.

This study reveals the large diversity of $P c a$ pathotypes as well as a surprisingly large number of virulence factors per pathotype in comparison with previous surveys. Nevertheless, many $P c$ resistance genes are still highly effective against crown rust races occurring in Poland. However, the use of these resistance genes in oat breeding programs should be conducted with care, avoiding the introduction of single $P c$ genes into oat cultivars or widespread deployment of the same varieties, which can lead to a uniform monoculture cropping system. Such practices would impose strong selection pressure on the pathogen, leading to the formation of dominant races and causing a rapid shift in pathotypes (Chong et al. 2008). Partial resistance to $P$. coronata should be considered as a promising alternative to single inherited genes, conferring complete race-specific resistance.

\section{Acknowledgments}

We thank the Research Centre for Cultivar Testing (Słupia Wielka, Poland) for providing crown rust-infected leaves from experimental stations across Poland. We also thank Dr. Tim Langdon (Institute of Biological, Environmental and Rural Sciences, Aberystwyth University, Aberystwyth, United Kingdom) for critical review of this manuscript before submission, Dr. Jennifer Mitchell Fetch (Agriculture and Agri-Food Canada, Brandon, MB, Canada), and Dr. James Chong (Agriculture and Agri-Food Canada, Morden, MB, Canada) for invaluable additional information about $P c$ differentials pedigrees.

\section{Literature Cited}

Bartos, P., Fleischmann, G., Samborski, D. J., and Shipton, W. A. 1969. Studies on asexual variation in the virulence of oat crown rust, Puccinia covonata $\mathrm{f}$. $\mathrm{sp}$. avenae, and wheat leaf rust, Puccinia recondita. Can. J. Bot. 47:1383-1387.

Berlin, A., Wallenhammar, A., and Andersson, B. 2018. Population differentiation of Puccinia coronata between hosts-implications for the epidemiology of oat crown rust. Eur. J. Plant Pathol. 152:901-907.

Brake, V. M., Irwin, J. A. G., and Park, R. F. 2001. Genetic variability in Australian isolates of Puccinia coronata f. sp. avenae assessed with molecular and pathogenicity markers. Australas. Plant Pathol. 30:259-266.

Carson, M. L. 2008. Virulence frequencies in oat crown rust in the United States from 2001 through 2005. Plant Dis. 92:379-384.

Carson, M. L. 2009a. Broad-spectrum resistance to crown rust, Puccinia coronata f. sp. avenae, in accessions of the tetraploid slender oat, Avena barbata. Plant Dis. 93:363-366.

Carson, M. L. 2009b. Cereal Disease Laboratory: Oat Crown Rust Race Survey Results-2008. https://www.ars.usda.gov/ARSUserFiles/50620500/Cerealrusts/ 2008ocr_survey.xls

Carson, M. L. 2009c. Crown rust development and selection for virulence in Puccinia coronata f. sp. avenae in an oat multiline cultivar. Plant Dis. 93: 347-353.

Carson, M. L. 2011. Virulence in oat crown rust (Puccinia coronata f. sp. avenae) in the United States from 2006 through 2009. Plant Dis. 95:1528-1534.

Chong, J. 2003. Disease of oat. Pages 74-88 in: Diseases of Field Crops in Canada K. Bailey, B. Gossen, R. Gugel, and R. Morrall, eds. CPS Press, Saskatoon, Canada.

Chong, J., Gruenke, J., Dueck, R., Mayert, W., Mitchell Fetch, J. W., and McCartney, C. A. 2011. Virulence of Puccinia coronata f. sp. avenae in the eastern prairie region of Canada during 2007-2009. Can. J. Plant Pathol. 33: 77-87.

Chong, J., Gruenke, J., Dueck, R., Mayert, W., and Woods, S. 2008. Virulence of oat crown rust Puccinia coronata f. sp. avenae in Canada during 2002-2006. Can. J. Plant Pathol. 30:115-123.

Chong, J., Leonard, K. J., and Salmeron, J. J. 2000. A North American system of nomenclature for Puccinia coronata f. sp. avenae. Plant Dis. 84:580-585.

Chong, J., and Zegeye, T. 2004. Physiologic specialization of Puccinia coronata f. sp. avenae, the cause of oat crown rust, in Canada from 1999 to 2001. Can. J. Plant Pathol. 26:97-108.

da Silva, L. P., Pereira Coutinho, A., Heleno, R. H., Tenreiro, P. Q., and Ramos, J. A. 2016. Dispersal of fungi spores by non-specialized flower-visiting birds. J. Avian Biol. 47:438-442.

Dice, L. R. 1945. Measures of the amount of ecologic association between species. Ecology 26:297-302.

Dong, S., Raffaele, S., and Kamoun, S. 2015. The two-speed genomes of filamentous pathogens: Waltz with plants. Curr. Opin. Genet. Dev. 35:57-65.

Fetch, T., McCallum, B., Menzies, J., Rashid, K., and Tenuta, A. 2011. Rust diseases in Canada. Prairie Soils Crops J. 4:86-96. 
Flor, H. H. 1971. Current status of the gene-for-gene concept. Annu. Rev. Phytopathol. 9:275-296.

Frey, K. J., Browning, J. A., and Simons, M. D. 1985. Registration of 'Multiline E76' and 'Multiline E77' oats. Crop Sci. 25:1125.

Gnanesh, B. N., Fetch, J. M., Zegeye, T., McCartney, C. A., and Fetch, T. 2014. Oat. Pages 51-73 in: Alien Gene Transfer in Crop Plants. A. Pratap and J. Kumar, eds. Springer, New York, NY.

Groth, J. V., and Roelfs, A. P. 1987. The concept and measurement of phenotypic diversity in Puccinia graminis on wheat. Phytopathology 77:1395-1399.

Hammer, Ø., Harper, D. A. T., and Ryan, P. D. 2001. PAST: Paleontological Statistocs Software Package for education and data analysis. Palaeontol. Electronica 4:1-9.

Harder, D. E., and Haber, S. 1992. Oat diseases and pathologic techniques. Pages 307-425 in: Oat Science and Technology. Marshall, H. G., and Sorrells, M. E., eds. American Society of Agronomy, Crop Science Society of America, Madison, WI.

Herrmann, A., Löwer, C. F., and Schachtel, G. A. 1999. A new tool for entry and analysis of virulence data for plant pathogens. Plant Pathol. 48:154-158.

Hovmøller, M. S., Justesen, A. F., and Brown, J. K. M. 2002. Clonality and longdistance migration of Puccinia striiformis f.sp. tritici in north-west Europe. Plant Pathol. 51:24-32.

Hsam, S. L. K., Peters, N., Paderina, E. V., Felsenstein, F., Oppitz, K., and Zeller, F. J. 1997. Genetic studies of powdery mildew resistance in common oat (Avena sativa L.) I. Cultivars and breeding lines grown in Western Europe and North America. Euphytica 96:421-427.

Jiráková, H., and Hanzalová, A. 2008. Crown rust pathotypes determined on oats in the Czech Republic from 2004 to 2006 and reaction to oat cultivars. Czech J. Genet. Plant Breed. 44:60-65.

Jones, J. D. G., and Dangl, J. L. 2006. The plant immune system. Nature 444: 323-329.

Klocke, B., Flath, K., and Miedaner, T. 2013. Virulence phenotypes in powdery mildew (Blumeria graminis) populations and resistance genes in triticale (x Triticosecale). Eur. J. Plant Pathol. 137:463-476.

Krattinger, S. G., and Keller, B. 2016. Molecular genetics and evolution of disease resistance in cereals. New Phytol. 212:320-332.

Limpert, E., Bartoš, P., Graber, W. K., Müller, K., and Fuchs, J. G. 2000. Increase of virulence complexity of nomadic airborne pathogens from west to east across Europe. Acta Phytopathologica et Entomologica Hungarica 35:261-272.

Limpert, E., Godet, F., and Müller, K. 1999. Dispersal of cereal mildews across Europe. Agric. For. Meteorol. 97:293-308.

McCartney, C. A., Stonehouse, R. G., Rossnagel, B. G., Eckstein, P. E., Scoles, G. J., Zatorski, T., Beattie, A. D., and Chong, J. 2011. Mapping of the oat crown rust resistance gene $P c 91$. Theor. Appl. Genet. 122:317-325.

McMullen, M. S., Doehlert, D. C., and Miller, J. D. 2005. Registration of 'HiFi'. Oat. Crop Sci. 45:1664.

Menzies, J. G., Xue, A., Dueck, R., and Greunke, J. 2015. Virulence of Puccinia coronata f. sp. avenae in Canada; 2010 to 2014. 14th International Cereal Rust and Powdery Mildew Conference, 5-8 July, Copenhagen, Denmark.

Miller, M. E., Zhang, Y., Omidvar, V., Sperschneider, J., Schwessinger, B., Raley, C., Palmer, J. M., Garnica, D., Upadhyaya, N., Rathjen, J., Taylor, J.M., Park, R. F., Dodds, P. N., Hirsch, C. D., Kianian, S. F., and Figueroa, M. 2018. De novo assembly and phasing of dikaryotic genomes from two isolates of Puccinia coronate f. sp. avenae, the causal agent of oat crown rust. MBio 9:1-21.

Mirek, Z., Piękoś-Mirkowa, H., Zając, A., and Zając, M. 2002. Flowering plants and pteridophytes of Poland. A checklist. Pages 1-442 in: Biodiversity of Poland. Z. Mirek, ed. Szafer Institute of Botany PAS, Cracow, Poland.
Müller, K., McDermott, J. M., Wolfe, M. S., and Limpert, E. 1996. Analysis of diversity in populations of plant pathogens: The barley powdery mildew pathogen across Europe. Eur. J. Plant Pathol. 102:385-395.

Nazareno, E. S., Li, F., Smith, M., Park, R. F., Kianian, S. F., and Figueroa, M 2018. Puccinia coronata f. sp. avenae: A threat to global oat production. Mol. Plant Pathol. 19:1047-1060.

Paczos-Grzęda, E., Okoń, S., Koroluk, A., and Kowalczyk, K. 2014. Ocena odporności na rdzę koronową nowych i historycznych polskich odmian owsa zwyczajnego (Assessing crown rust resistance of modern and old Polish common oat cultivars). Folia Pomer. Univ. Technol. Stetin., Agric., Aliment. Pisc. Zootech. 310:85-92.

Park, R. F. 2008. Breeding cereals for rust resistance in Australia. Plant Pathol. 57: 591-602.

Park, R. F. 2013. New oat crown rust pathotype with virulence for Pc91. Cereal Rust Rep. 11:1-3.

Park, R. F., and Wellings, C. R. 2012. Somatic hybridization in the uredinales Annu. Rev. Phytopathol. 50:219-239.

Payne, L. X., Schindler, D. E., Parrish, J. K., and Temple, S. A. 2005. Quantifying spatial pattern with evenness indices. Ecol. Appl. 15:507-520.

Periyannan, S., Milne, R. J., Figueroa, M., Lagudah, E. S., and Dodds, P. N. 2017. An overview of genetic rust resistance: From broad to specific mechanisms. PLoS Pathog 13:e1006380.

Rooney, W. L., Rines, H. W., and Phillips, R. L. 1994. Identification of RFLP markers linked to crown rust resistance genes $P c 91$ and $P c 92$ in oat. Crop Sci. 34:940-944

Šebesta, J., Zwatz, B., Harder, D. E., Corazza, L., and Stojanovic, S. 1997 Incidence of crown rust and virulence of Puccinia coronata on oat and the effectiveness of $P c$-genes for resistance in Europe during 1990-1994. Arch Phytopathol. Plant Prot. 30:507-518

Šebesta, J., Zwatz, B., Roderick, H., Corazza, L., Manisterski, J., and Stojanovic, S. 2003. Incidence of crown rust and virulence of Puccinia coronata cda. f.sp. avenae eriks. and the effectiveness of $P c$ genes for resistance in Europe, Middle East and North Africa. Arch. Phytopathol. Plant Prot. 36:179-194

Simons, M. D. 1985. Crown rust. Pages 131-172 in: The Cereal Rust, Volume II: Diseases, Distribution, Epidemiology, and Control. A. P. Roelfs and W. R. Bushnel, eds. Academic Press, Orlando, FL.

Simons, M. D., Martens, J. W., McKenzie, R. I. H., Nishiyama, I., Sadanaga, K., Šbesta, J., and Thomas, H. 1978. Oats: A Standardized System of Nomenclature for Genes and Chromosomes and Catalog of Genes Governing Characters. Science and Education Administration, U.S. Department of Agriculture, ed. Science and Education Administration and Iowa Agricultural and Home Economics Experiment Station, Washington, DC.

Simpson, E. H. 1949. Measurement of diversity. Nature 163:688.

Smith, L. 2002. A Tutorial on Principal Components Analysis. http://www.cs otago.ac.nz/cosc453/student_tutorials/principal_components.pdf

Sowa, S., Paczos-Grzęda, E., Koroluk, A., Okoń, S., Ostrowska, A., Ociepa, T. Chrzasstek, M., and Kowalczyk, K. 2016. Resistance to Puccinia coronatc f. sp. avenae in Avena magna, A. murphyi, and A. insularis. Plant Dis. 100: 1184-1191

StatSoft. 2017. Statistica 13.1. (data analysis software system). Tulsa, OK.

Tinline, R. D., and MacNeill, B. H. 1969. Parasexuality in plant pathogenic fungi. Annu. Rev. Phytopathol. 7:147-168.

Zhao, J., Wang, M., Chen, X., and Kang, Z. 2016. Role of alternate hosts in epidemiology and pathogen variation of cereal rusts. Annu. Rev. Phytopathol. 54:207-228. 